\title{
A novel diffuse large B-cell lymphoma-associated cancer testis antigen encoding a PAS domain protein
}

\author{
AP Liggins",', PJ Brown', K Asker', K Pulford' and AH Banham' \\ 'Nuffield Department of Clinical Laboratory Sciences, University of Oxford, LRF Immunodiagnostics Unit, Level 4 Academic Block, John Radcliffe Hospital, \\ Oxford, Oxfordshire OX3 9DU, UK
}

\begin{abstract}
Here we report that the OX-TES-I SEREX antigen, which showed immunological reactivity with serum from four out of I0 diffuse large B-cell lymphoma (DLBCL) patients, is encoded by a novel gene, PAS domain containing I (PASD I). PASDI_VI cDNA encodes a 639 amino-acid (aa) protein product, while an alternatively spliced variant (PASD I_v2), lacking intron I4, encodes a 773 aa protein, the first 638 aa of which are common to both proteins. The PASDI-predicted protein contains a PAS domain that, together with a putative leucine zipper and nuclear localisation signal, suggests it encodes a transcription factor. The expression of PASD I_v I mRNA was confirmed by RT-PCR in seven DLBCL-derived cell lines, while PASD I_v2 mRNA appears to be preferentially expressed in cell lines derived from non-germinal centre DLBCL. Immunophenotyping studies of de novo DLBCL patients' tumours with antibodies to CDI0, BCL-6 and MUMI indicated that two patients mounting an immune response to PASDI were of a poor prognosis nongerminal centre subtype. Expression of PASD / mRNA was restricted to normal testis, while frequent expression was observed in solid tumours (25 out of 68 ), thus fulfilling the criteria for a novel cancer testis antigen. PASDI has potential for lymphoma vaccine development that may also be widely applicable to other tumour types.

British Journal of Cancer (2004) 9 I, |4I-149. doi: I0.1038/sj.bjc.660I875 www.bjcancer.com
\end{abstract}

Published online 25 May 2004

(c) 2004 Cancer Research UK

Keywords: cancer testis antigen; lymphoma; SEREX; PAS domain

Diffuse large B-cell lymphoma (DLBCL) is the most common form of adult non-Hodgkin's lymphoma and is heterogeneous with respect to morphology, clinical features and immunophenotype (Jaffe et al, 2001). Approximately 50\% of DLBCL patients relapse after conventional anthracycline-based CHOP-type treatment (The Non-Hodgkin's Lymphoma Classification Project, 1997). Gene expression studies have identified clinically-relevant subtypes of DLBCL, showing that patients with a germinal centre-derived tumour have an improved prognosis compared to those with a non-germinal centre-derived tumour (Alizadeh et al, 2000; Rosenwald et al, 2002). Improving the outcome for these patients requires both the identification of high-risk patients at diagnosis and the development of alternative effective therapeutic strategies.

There is increasing evidence for the existence of an anti-tumour immune response against proteins expressed by malignant cells. Antibodies to tumour-associated proteins have been found in the blood of cancer patients and these antibodies can be exploited to enable the identification of tumour-associated proteins using SEREX (serological analysis of recombinant cDNA expression libraries). This technique has been used in a number of laboratories to identify more than 2000 tumour-associated antigens (Türeci et al, 1999; Preuss et al, 2002). Since these antigens have included molecules that were originally identified by cloning cytotoxic $\mathrm{T}$

*Correspondence: Dr A Liggins; E-mail: amanda.liggins@ndcls.ox.ac.uk Received 19 January 2004; revised 10 March 2004; accepted 25 March 2004; published online 25 May 2004 lymphocyte (CTL)-recognised epitopes, for example, MAGE-1 and tyrosinase (van der Bruggen et al, 1991; Brichard et al, 1993; Sahin et al, 1995), SEREX can be used to detect tumour antigens eliciting both cellular and humoral immunity.

Cancer testis antigens (CTAs) constitute some of the most promising tumour-associated antigen candidates for therapeutic development, being normally expressed only in immunologicallyprivileged sites such as the testis, but also in neoplastic cells (Scanlan et al, 2002). Examples of CTAs currently being used for immunotherapy include NY-ESO-1 and MAGE-A3 peptides in melanoma (Coulie et al, 2001; Jäger et al, 2001). However, it should be noted that other categories of SEREX antigens, such as the overexpressed HER-2/neu protein, are being targeted with some success in the treatment of breast carcinomas (Bernhard et al, 2002). SEREX antigens can also be used as adjuvants to boost the immune response to other tumour antigens (Nishikawa et al, 2001).

We have previously used SEREX to identify 28 proteins whose expression might be relevant to the pathogenesis of DLBCL, and which may provide potential novel immunotherapeutic targets (Liggins et al, 2004). One of the antigens, OX-TES-1, was recognised by serum from four out of 10 patients with DLBCL, one out of 20 normal serum samples and no acute myeloid leukaemia (AML) or chronic myeloid leukaemia (CML) serum samples $(n=10$ of each). This report describes the sequence and genomic organisation of the gene encoding this antigen, $P A S$ domain containing 1 (PASD1), and the identification of an alternatively spliced variant, $P A S D 1 \_v 2$, both variants being expressed in DLBCL cell lines. Expression studies indicate that 
PASD1 is a novel CTA showing widespread mRNA expression in patients with solid tumours and in DLBCL-derived cell lines.

\section{MATERIALS AND METHODS}

\section{Tissue samples}

This project was approved by the Oxford Clinical Research Ethics Committee and informed patient consent was obtained prior to the collection of serum samples used in the SEREX screening. Tissue biopsies from the DLBCL patients were obtained from the Department of Pathology, John Radcliffe Hospital, Oxford.

\section{Cell lines and culture conditions}

The OCI-Ly3, OCI-Ly10 (activated B-cell-derived), SUDHL-6, SUDHL-10 and DB (germinal centre-derived) DLBCL cell lines were a kind gift from Dr Eric Davis and Dr Andreas Rosenwald, Bethesda, MD, USA, and the LIB, MIEU, DEAU and HLY-1 DLBCL cell lines were generously provided by Dr Talal Al Saati, Toulouse, France. These cell lines were maintained in RPMI 1640 medium (Sigma Aldrich, UK) supplemented with $10 \%$ foetal calf serum and antibiotics (penicillin $\left(5000 \mathrm{U} \mathrm{ml}^{-1}\right)$ and streptomycin $\left(5000 \mu \mathrm{g} \mathrm{ml}^{-1}\right)$, Invitrogen, $\left.\mathrm{UK}\right)$ in an atmosphere of $5 \% \mathrm{CO}_{2}$ at $37^{\circ} \mathrm{C}$. Cells were washed in RNase-free PBS prior to mRNA extraction.

\section{OX-TES-1 expression cloning and sequencing}

A single cDNA clone encoding the full-length OX-TES-1 antigen was isolated as previously described using SEREX (Liggins et al, 2004). The cDNA insert was commercially sequenced to publication quality by MWG Biotech (GenBank Accession Number AY270020).

\section{Hybridisation of the PASD1 cDNA to expression arrays}

Multiple tissue expression (MTE) and matched tumour/normal (MTN) arrays (BD Biosciences Clontech, CA, USA) were prehybridised according to the manufacturer's instructions. A $610 \mathrm{bp}$ Pst 1 fragment of PASD1_v1, also present in the splice variant (PASD1_v2) and representing a portion of the $3^{\prime}$ UTR, was radiolabelled using the High Prime DNA Labelling Kit (Roche Molecular Biochemicals, UK). This probe was hybridised to both arrays, according to the manufacturer's instructions, before exposure to film at $-70^{\circ} \mathrm{C}$ for 27 days. Additional information about the tissues and cases on these arrays can be obtained from the BD Biosciences Clontech website (www.bdbiosciences.com/clontech). Loading of the cDNAs on the MTN and MTE arrays is normalised for three and eight housekeeping genes respectively to enable quantitative comparisons between gene expression in different tissues. As an additional loading control, a radiolabelled ubiquitin cDNA probe was subsequently hybridised to the stripped array according to the manufacturer's instructions.

\section{Reverse transcription-polymerase chain reaction}

Reverse transcription - polymerase chain reaction (RT-PCR) was carried out as follows: Poly(A) + mRNA from the seven DLBCLderived cell lines was extracted using $\mu$ MACS mRNA Isolation kits (Miltenyi Biotech, Germany). The cDNA was reverse transcribed at $42^{\circ} \mathrm{C}$ for $50 \mathrm{~min}$ from $20 \mathrm{ng} \mathrm{mRNA}$ in a $25 \mu \mathrm{l}$ reaction containing $200 \mathrm{U}$ Superscript $\mathrm{II}^{\mathrm{TM}}$ RNase $\mathrm{H}^{-}$reverse transcriptase (Invitrogen, UK), $1 \times$ First Strand Buffer, $4 \mathrm{~mm}$ DTT and $100 \mathrm{ng}$ of either oligo(dT) primer or random hexamers. The integrity of cDNA templates was assessed using gene-specific primers to $\beta$-actin. $2 \mu \mathrm{l}$ of cDNA was amplified in a $25 \mu \mathrm{l}$ PCR reaction containing $200 \mu \mathrm{M}$ each dNTP, $4 \mu \mathrm{M}$ each primer, $1 \times$ PCR buffer and $1 \times$ Advantage 2 Polymerase mix (BD Biosciences Clontech, CA, USA). Genespecific primers were designed to amplify fragments of 211$1505 \mathrm{bp}$. Primer pair A: forward: 5'-TACAGGAGCGGAA GAAGTGG-3'; reverse: $5^{\prime}$-ACAGGAACAATGGGTTGGG-3'; primer pair B: forward: $5^{\prime}$-TCTCATCAATAGCAACTTGCTC- $3^{\prime}$; reverse: $5^{\prime}$ - TCACACTCACTTCCCTCTTAC- $3^{\prime}$; and primer pair C: forward: 5'-TCCAGAGAGCAGGCTGAACAA-3', reverse: 5'-AAGCCGGATG TAATCCTGTG-3'. Cycling parameters were as follows: $5 \mathrm{~min}$ at $94^{\circ} \mathrm{C}$ (initial denaturation) then $45 \mathrm{~s}$ at $94^{\circ} \mathrm{C}, 45 \mathrm{~s}$ at appropriate annealing temperature $\left(\mathrm{A} 60^{\circ} \mathrm{C}, \mathrm{B} 55^{\circ} \mathrm{C}, \mathrm{C} 60^{\circ} \mathrm{C}\right)$ and $2.5 \mathrm{~min}(\mathrm{~A}$ and $\mathrm{B}$ ) or $5 \mathrm{~min}(\mathrm{C})$ at $72^{\circ} \mathrm{C}$ for 30 (A and $\mathrm{B}$ ) or 35 (C) cycles. Phagemid DNA containing the appropriate cDNA insert was used as a positive control, while the negative control was a PCR mixture with no cDNA template. Reactions were also carried out on cDNA synthesis reactions that lacked reverse transcriptase. PCR products were visualised after separation in agarose gels by staining with ethidium bromide.

\section{Immunohistochemistry}

Formalin-fixed paraffin-embedded sections from the DLBCL biopsies were dewaxed/rehydrated and then antigen retrieval was performed by microwave pressure cooking for $3 \mathrm{~min}$ in $50 \mathrm{~mm}$ Tris; $1 \mathrm{~mm}$ EDTA ( $\mathrm{pH} 9$ ). Immunostaining was performed using the DAKO Envision system with primary antibodies to CD10 (Novocastra), BCL-6 (DAKO) or MUM1 (a kind gift from Professor B Falini, Perugia). The stained sections were counterstained with haematoxylin and mounted in Aquamount (VWR).

\section{RESULTS}

The single cDNA clone encoding the OX-TES-1 antigen was identified by screening a testis library with serum from a single patient with aggressive DLBCL as previously described (Liggins et al, 2004). The $4.2 \mathrm{~kb}$ cDNA insert from the phagemid was fully sequenced. Sequence searches at the time the gene was cloned, using the BLAST search engine at the National Center for Biotechnology Information, indicated that the cDNA sequence represented a novel gene that had not been deposited in the public databases.

\section{Sequence analysis of $P A S D 1$ and identification of an alternatively spliced form, PASD1_v2}

A UniGene folder (Hs.160594) has recently been created for this gene, which encodes an unnamed protein product and maps to Xq28. The HUGO gene nomenclature committee has named the gene PAS domain containing 1 (PASD1). A recently-sequenced human testis MGC clone (BC040301) contains a smaller cDNA $(2850 \mathrm{bp})$ encoding a longer PASD1 protein product that we have named PASD1_v2. Subsequently, when specifically referring to our variant, we use the name PASD1_v1. A comparison of both the PASD1_v1 and PASD1_v2 cDNA sequences with the human genome sequence demonstrated that these are alternatively spliced, with the $1.27 \mathrm{~kb}$ sequence corresponding to intron 14 being retained within the PASD1_v1 transcript (Figure 1).

Translation of the PASD1 cDNA sequence predicted the existence of two potential methionine start codons for this protein; since the second (aa3) has a slightly better Kozak consensus sequence (Kozak, 1987) than the first, it may represent the start of translation. Both PASD1_v1 and PASD1_v2 encode a predicted protein product with identical N-terminal sequence (638 aa). The retained intron in PASD1_v1 introduces a stop codon after aa 639, while PASD1_v2 encodes an additional 134 aa at the C-terminus (Figure 2). The poly(A) tail and the presence of upstream stop 


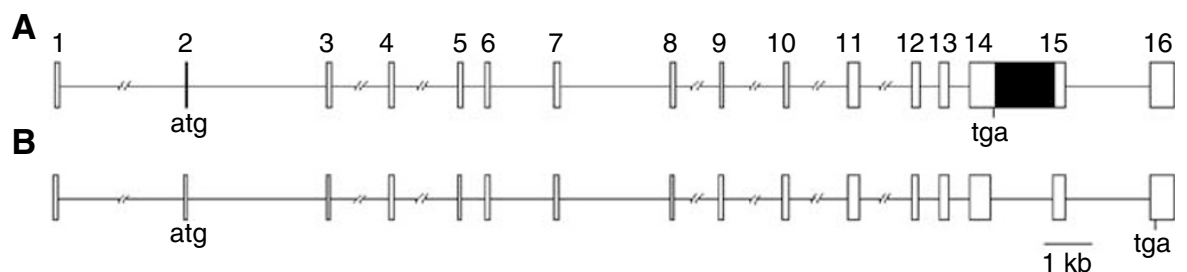

Figure I Genomic structure of PASDI_vI (A) and PASDI_v2 (B). Exons are indicated as open boxes, introns as lines and the retained intron in PASD I_vI is indicated with a black box. The position of predicted translational start and stop sites are indicated.

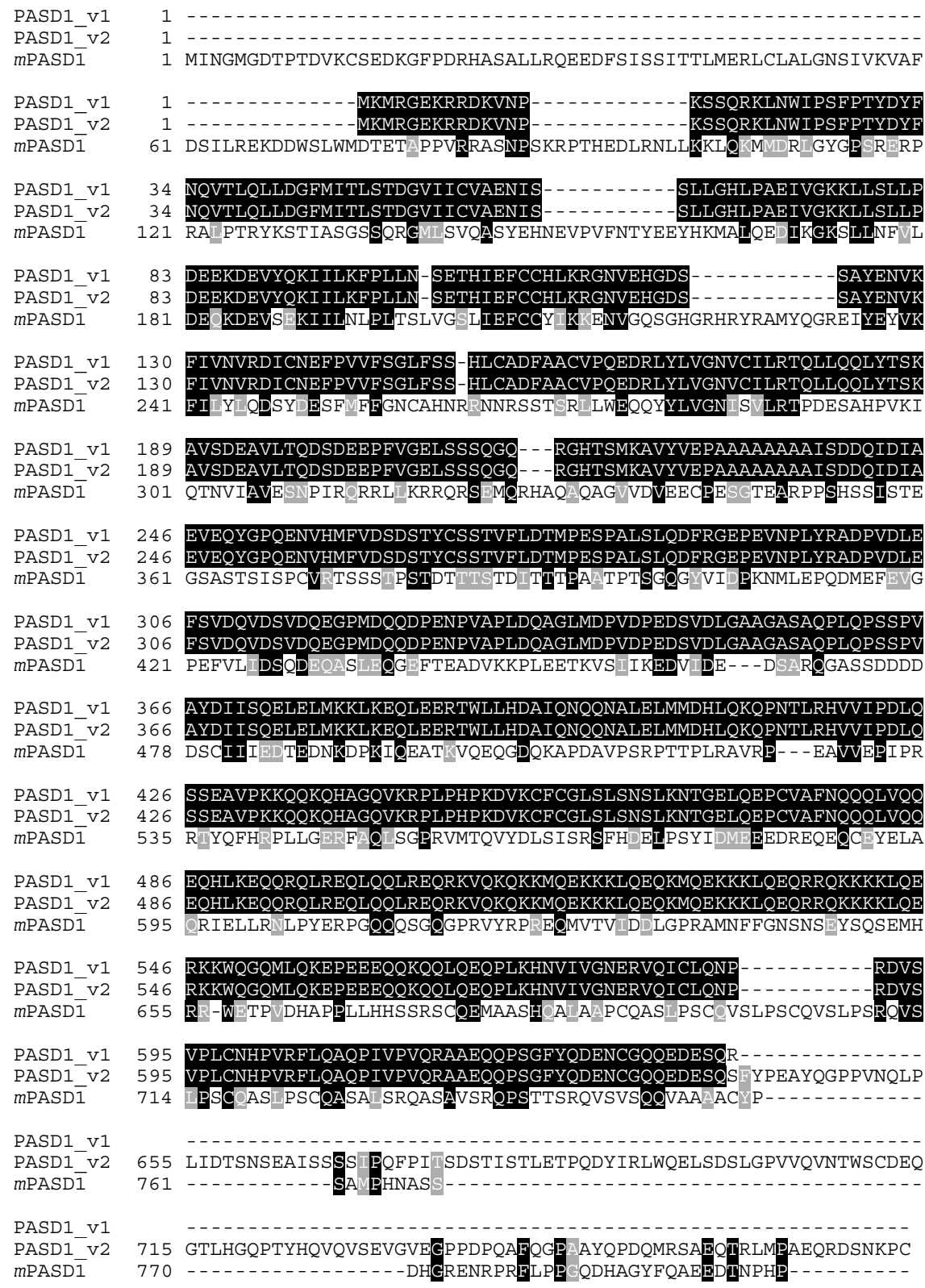

Figure 2 PASDI_vI and PASDI_v2 proteins, along with the murine homologue, mPASDI. Identical residues are highlighted while similar residues are shaded in grey. The murine protein shows $35.7 \%$ similarity (25.2\% identity) with PASDI_vI and 34.I\% similarity (24.2\% identity) with PASDI_V2.

codons before the translated protein sequence indicated that a fulllength PASD1_v1 cDNA had been isolated. A hypothetical gene similar to LOC139135 in UniGene Mm.295937 may represent the murine homologue of PASD1 (Figure 2); this gene also maps to the $\mathrm{X}$ chromosome.

\section{Sequence analyses of the PASD1 protein}

Analyses of the human PASD1 protein sequence using databases on the World Wide Web predict the presence of a number of domains, several of which are illustrated in Figure 3. Analysis 
A

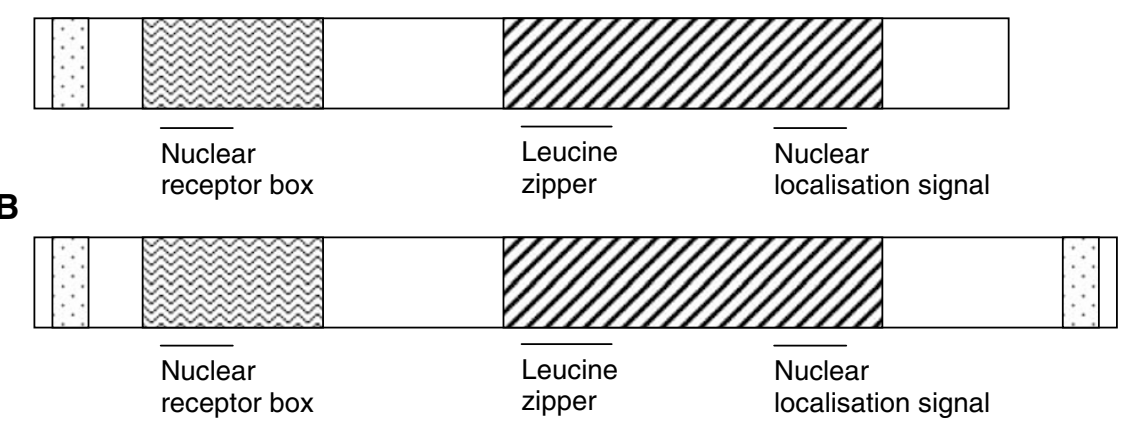

洨 PAS domain Coiled coil domain $\because$ ER retention signal

Figure 3 Schematic illustration of the domains within the PASDI_vI (A) and PASDI_v2 (B) proteins (not to scale). Additional domains are underlined.

A

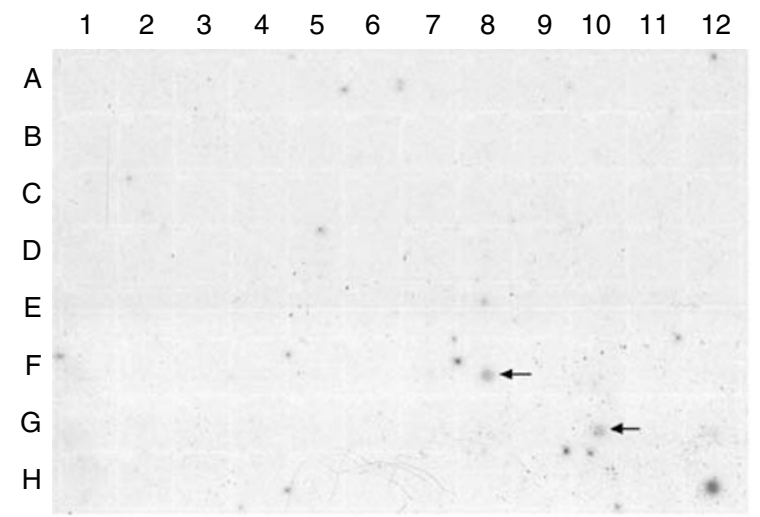

B

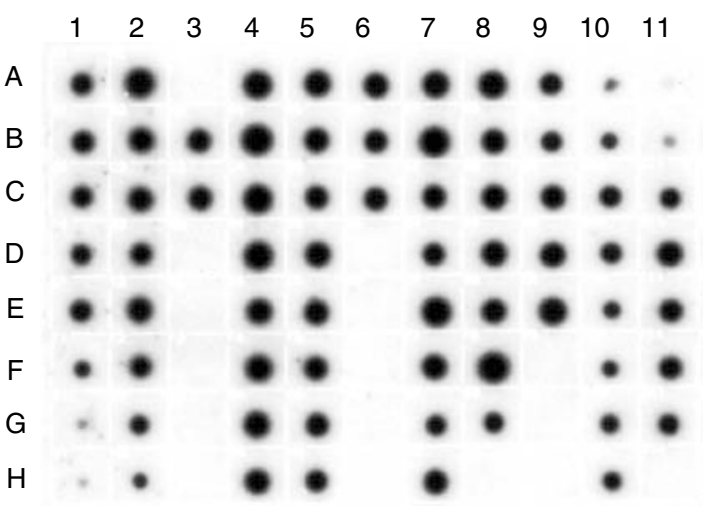

\begin{tabular}{|c|c|c|c|c|c|c|c|c|c|c|c|}
\hline 1 & 2 & 3 & 4 & 5 & 6 & 7 & 8 & 9 & 10 & 11 & 12 \\
\hline $\begin{array}{l}\text { Whole } \\
\text { brain }\end{array}$ & $\begin{array}{c}\text { Cerebellum, } \\
\text { left }\end{array}$ & & Heart & Oesophagus & $\begin{array}{c}\text { Colon, } \\
\text { transverse }\end{array}$ & Kidney & Lung & Liver & $\begin{array}{l}\text { Leukemia, } \\
\text { HL-60 }\end{array}$ & $\begin{array}{l}\text { Total } \\
\text { brain }\end{array}$ & $\begin{array}{c}\text { Yeast } \\
\text { total RNA }\end{array}$ \\
\hline $\begin{array}{c}\text { Cerebral } \\
\text { cortex }\end{array}$ & $\begin{array}{c}\text { Cerebellum, } \\
\text { right }\end{array}$ & $\begin{array}{c}\text { Accumbena } \\
\text { nucleus }\end{array}$ & Aorta & Stomach & $\begin{array}{c}\text { Colon, } \\
\text { desending }\end{array}$ & $\begin{array}{l}\text { Skeletal } \\
\text { muscle }\end{array}$ & Placenta & Pancreas & $\begin{array}{c}\text { Hela } \\
\text { S3 }\end{array}$ & $\begin{array}{l}\text { Fetal } \\
\text { heart }\end{array}$ & $\begin{array}{l}\text { Yeast } \\
\text { tRNA }\end{array}$ \\
\hline $\begin{array}{c}\text { Frontal } \\
\text { lobe }\end{array}$ & $\begin{array}{c}\text { Corpus } \\
\text { collostum }\end{array}$ & Thalmus & $\begin{array}{l}\text { Atrium, } \\
\text { left }\end{array}$ & Duodenum & Rectum & Spleen & Bladder & $\begin{array}{l}\text { Adrenal } \\
\text { gland }\end{array}$ & $\begin{array}{c}\text { Leukemia, } \\
\text { k-562 }\end{array}$ & $\begin{array}{c}\text { Total } \\
\text { kidney }\end{array}$ & $\begin{array}{l}\text { E coli } \\
\text { rRNA }\end{array}$ \\
\hline $\begin{array}{l}\text { Parietal } \\
\text { lobe }\end{array}$ & Amygdala & & $\begin{array}{l}\text { Atrium, } \\
\text { right }\end{array}$ & Jejunum & Thymus & & Uterus & $\begin{array}{l}\text { Thyroid } \\
\text { gland }\end{array}$ & $\begin{array}{c}\text { Leukemia, } \\
\text { MOLT-4 }\end{array}$ & $\begin{array}{l}\text { Fetal } \\
\text { liver }\end{array}$ & $\begin{array}{l}\text { E coli } \\
\text { DNA }\end{array}$ \\
\hline$E \mid \begin{array}{c}\text { Occipital } \\
\text { lobe }\end{array}$ & $\begin{array}{c}\text { Caudate } \\
\text { nucleus }\end{array}$ & & $\begin{array}{c}\text { Ventricle, } \\
\text { left }\end{array}$ & Ileum & $\begin{array}{l}\text { Peripheral } \\
\text { blood } \\
\text { leukocyte }\end{array}$ & & Prostate & $\begin{array}{l}\text { Salivary } \\
\text { gland }\end{array}$ & $\begin{array}{c}\text { Burkitt's } \\
\text { lymphoma, } \\
\text { Raji }\end{array}$ & \begin{tabular}{|c|} 
Fetal \\
spleen
\end{tabular} & Poly r $[A]$ \\
\hline F $\begin{array}{c}\begin{array}{c}\text { Temporal } \\
\text { lobe }\end{array} \\
\end{array}$ & $\begin{array}{l}\text { Hippo- } \\
\text { campus }\end{array}$ & & $\begin{array}{c}\text { Ventricle, } \\
\text { right }\end{array}$ & Ilocecum & $\begin{array}{c}\text { Lymph } \\
\text { node }\end{array}$ & & Testis & & $\begin{array}{c}\text { Burkitt's } \\
\text { lymphoma, } \\
\text { daudi }\end{array}$ & $\begin{array}{c}\text { Fetal } \\
\text { thymus }\end{array}$ & $\begin{array}{l}\text { Human } \\
\mathrm{C}_{0} \mathrm{t}-1 \mathrm{DNA}\end{array}$ \\
\hline$G \mid$\begin{tabular}{c|}
$\begin{array}{c}\text { P.g. }{ }^{*} \text { of } \\
\text { cerebral } \\
\text { cortex }\end{array}$ \\
\end{tabular} & $\begin{array}{l}\text { Medulla } \\
\text { oblongata }\end{array}$ & & \begin{tabular}{|c|} 
Inter- \\
ventricular \\
septum
\end{tabular} & Appendix & $\begin{array}{l}\text { Bone } \\
\text { marrow }\end{array}$ & & Ovary & & $\begin{array}{c}\text { Coloractal } \\
\text { adeno- } \\
\text { carcinoma, } \\
\text { SW480 } \\
\end{array}$ & $\begin{array}{l}\text { Fetal } \\
\text { lung }\end{array}$ & $\begin{array}{c}\text { Human } \\
\text { DNA } \\
100 \mathrm{ng}\end{array}$ \\
\hline Pons & Putamen & & $\begin{array}{c}\text { Apex of } \\
\text { the heart }\end{array}$ & $\begin{array}{l}\text { Colon, } \\
\text { ascending }\end{array}$ & Trachea & & & & $\begin{array}{c}\text { lung } \\
\text { carcinoma, } \\
\text { A549 }\end{array}$ & & $\begin{array}{l}\text { Human } \\
\text { DNA } \\
500 \mathrm{ng}\end{array}$ \\
\hline
\end{tabular}

*Paracentral gyrus

Figure 4 Results obtained from hybridising the PASD I CDNA (A) or the ubiquitin cDNA control probe (B) to BD Biosciences' MTE array. The identity and position of tissues on the array is shown in the lower panel $(\mathbf{C})$. The positive signals for PASD I are arrowed.

using the programme MotifFinder identified two overlapping Nterminal PAS (Per ARNT Sim) domains (using the Pfam and Prosite databases) between aa 32-94 and aa 41-137. Analysis using the PSORT II programme identified an R-2 motif at aa 14 (which is a predicted cleavage site for mitochondrial presequence), a nuclear localisation signal at aa 539, an ER membrane retention 


\section{A}
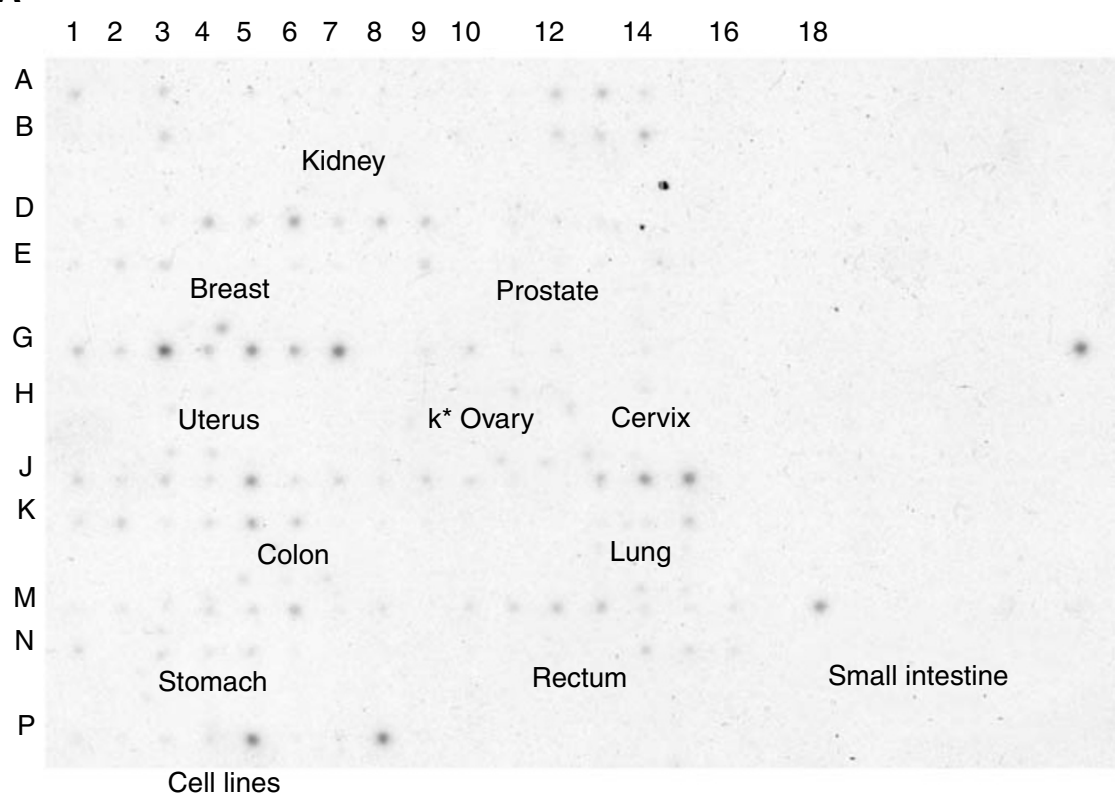

B

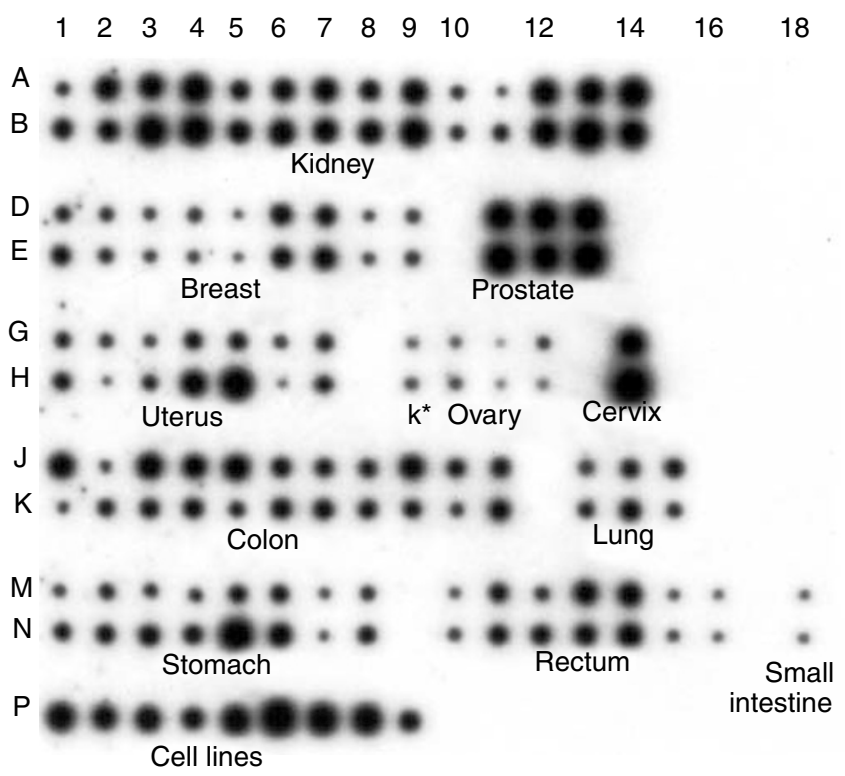

Figure 5 Results obtained from hybridising the PASD/ cDNA (A) or the ubiquitin cDNA control probe (B) to BD Biosciences' MTN expression array. The identity and position of tissues on the array are shown. Rows $A, D, G, J$, and $M$ are normal tissue while $B, E, H, K$, an $N$ are tumour tissue, $K *$ kidney. Row P indicates the human cancer cell lines: I - HeLa, 2 - Daudi (Burkitt's lymphoma), 3 - K562 (chronic myeloid leukaemia), 4 - HL-60 (promyelocytic leukaemia), 5 - G36I (melanoma), 6 - A549 (lung carcinoma), 7 - MOLT-4 (lymphoblastic leukaemia), 8 - SW480 (colorectal adenocarcinoma), and 9 Raji (Burkitt's lymphoma).

signal at the $\mathrm{N}$-terminus, a C-terminal leucine zipper pattern between aa $482-503$ and a coiled-coil domain between aa $476-$ 557. An LXXLL motif or nuclear receptor (NR) box was also detected in the N-terminus of the PASD1 protein between aa $77-$ 81. In addition to the domains illustrated, there is a proline-rich region between aa $478-639$, a lysine-rich region between aa $508-$ 548 , and a glutamine-rich region between aa $479-638$. There is only one domain, an ER membrane retention signal between aa $769-772$, in the additional region encoded by PASD1_v2.

Database searches using the PASD1 protein sequence have shown that the most closely related proteins, other than the murine homologue, are the neuronal PAS domain protein 2 of the zebrafish Danio rerio (34\% identity) and the CLOCK protein of the Korean rock fish Sebastes schlegeli (32\%).

\section{Expression of PASD1 mRNAs in normal human tissues}

A normal tissue-derived MTE cDNA array, prepared from pooled individuals that are non-diseased victims of sudden death/trauma, was probed with a cDNA fragment that is common to both PASD1_v1 and PASD1_v2. The expression of the PASD1 mRNA in both adult and foetal normal human tissues was shown to be restricted to testis (Figure 4A). This gene is expressed at very low levels requiring a long exposure time to obtain the data illustrated 
A

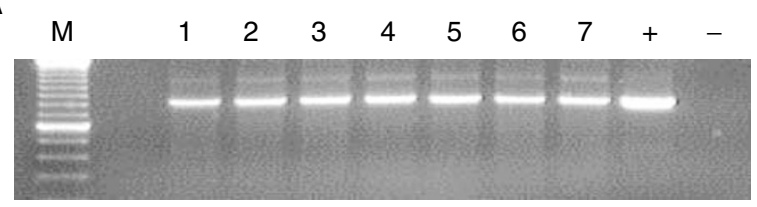

B

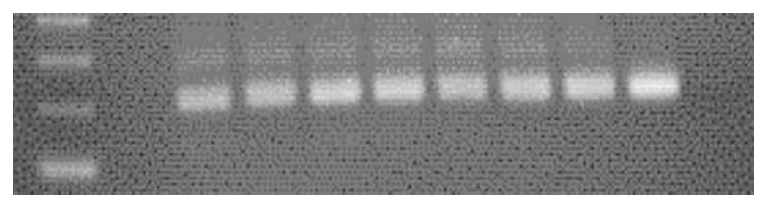

C

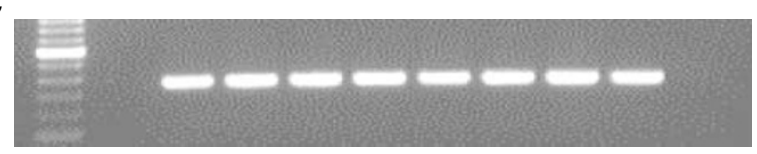

D

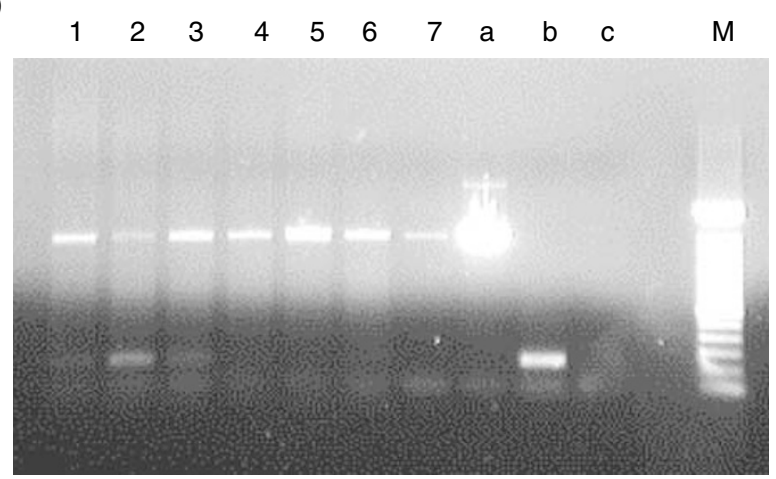

Figure 6 PASD / products amplified by RT-PCR from DLBCL cell lines: $(\mathbf{A}): \beta$-actin control; (B): $\mathrm{PCR}$ with primer set $\mathrm{A}$ (detects both transcripts, same size product); (C): PCR with primer set B (PASD I_vl specific): $M=100$ bp ladder; I-7= cell lines (in order): OCl-Ly3; OCl-Lyl O; HLY-I; SUDLH6; MIEU; LIB; DEAU; + = positive control; - = negative control (D): PCR with primer set C (PASD I_v / large product and PASD I_v2 small product) $M=100 \mathrm{bp}$ ladder; $\mathrm{I}-6=$ cell lines (in order): OCl-Ly3; OCl LyI0; HLY-I; SUDLH6; SUDHLI0; DB; 7 = genomic DNA; a = PASDI_vl positive control; $b=$ PASD I_v2 positive control; $c=$ negative control.

and repetition confirmed this result. Our expression data are supported by the normal tissue sources of EST sequences in UniGene folders Hs.160594 and Mm.295937, all of which have been isolated from testis (or pooled samples containing testis). Furthermore, both the PASD_v1 and PASD1_v2 cDNAs were isolated from testis cDNA libraries. The other positive signals seen on this array are those from a colorectal adenocarcinoma cell line and the human DNA (500 ng) control.

\section{Expression of PASD1 mRNAs in neoplastic tissues}

The same cDNA probe was used to analyse the expression of PASD1 mRNA in human tumours and adjacent histologicallynormal tissue (taken from the same cancer patients) on the MTN array (Figure 5A). Although PASD1 expression was restricted to testis in normal individuals, the histologically 'normal' tissues were frequently found to express this gene. In some tissues, most notably breast, uterus, small intestine and lung, there was often higher expression in the 'normal' tissues than was observed in the paired tumour tissue. The results obtained after rehybridising the array with a ubiquitin probe confirmed that this was not caused by differences in sample loading (Figure $5 \mathrm{~B}$ ). A possible explanation for this observation is that changes in PASD1 expression may be

an early event in carcinogenesis that occurs before histological changes are apparent. The PASD1 mRNA is shown to be expressed in 25 of the 68 solid tumour tissues included on the MTN array. PASD1 expression was also seen in the human cancer cell lines (Figure 5A, Row P), with the melanoma (P5) and colorectal adenocarcinoma (P8) cell lines showing the highest expression levels. Incidentally, the colorectal adenocarcinoma cell line on the MTN array is the same as that on the MTE array, where it also gave a positive signal (Figure 4A). Other cell lines common to both arrays showed very weak expression on the MTN array, while no signal was observed on the normal tissue MTE array. However, probing the arrays with ubiquitin as a loading control indicated that the cDNAs for these cell lines were under-represented on the MTE array.

\section{Expression of the PASD1_v1 and PASD1_v2 mRNAs in DLBCL cell lines}

Since the PASD1 cDNA was originally cloned from a testis cDNA library, RT-PCR was used to confirm whether the PASD1 mRNA was expressed in a panel of DLBCL-derived cell lines. Products were obtained with all cell lines using primers to $\beta$-actin (Figure 6A), indicating the integrity and suitability of the cDNAs as templates for PCR. Analysis of PASD1 mRNA expression with primer set A successfully amplified fragments of the same size as the positive control $(211 \mathrm{bp})$ in all DLBCL cell lines tested (Figure 6B). Primer set A was designed to amplify a region of cDNA common to both PASD1_v1 and PASD1_v2 and therefore does not distinguish these two mRNA species.

To confirm the expression of the PASD1_v1 mRNA, RT-PCR was carried out with primers designed to the retained intronic sequence that is absent in PASD1_v2 (primer set $\mathrm{B}$ ). Figure 6C shows that a fragment of the same size as the positive control ( $360 \mathrm{bp}$ ) was successfully amplified in all DLBCL cell lines. This confirms that the PASD1_v1 mRNA is transcribed in DLBCLderived cell lines.

The PASD1_v2 cDNA does not contain any unique sequence that could be used to determine whether both variants are transcribed in DLBCL. Therefore, RT-PCR was carried out with primers designed to regions in exons 14 and 15 that flank the retained intronic sequence (primer set C). With these primers, a $1505 \mathrm{bp}$ fragment indicates the expression of PASD1_v1, while a $238 \mathrm{bp}$ fragment indicates the expression of PASD1_v2. Figure 6D shows that a product of $\sim 1500 \mathrm{bp}$ is amplified in all the DLBCL cell lines. A smaller product of $\sim 240 \mathrm{bp}$, was observed in the OCI-Ly3, OCILy10 and HLY-1 cell lines suggesting that PASD1_v2 is transcribed in DLBCL-derived cell lines of a non-germinal centre phenotype. No products were obtained when PCR was performed on cDNA synthesis reactions that lacked reverse transcriptase (data not shown) indicating that there was no genomic DNA contamination and the products obtained are amplified from cDNA.

\section{Immunophenotyping of patients}

In the original SEREX study, serum from 10 DLBCL patients was tested for the presence of antibodies to the PASD1 protein. Three of these patients had DLBCL transformation from follicular lymphoma, which generally has a poor prognosis; one of these patients showed a humoral immune response to the PASD1 protein. The remaining patients, including the patient whose serum sample was used for SEREX screening, were diagnosed with de novo DLBCL. According to Hans et al (2004), immunohistochemical labelling using monoclonal antibodies to the germinal centre markers CD10, BCL- 6 and the non-germinal centre marker MUM1 can be used to distinguish good prognosis (germinal centre) and high-risk (non-germinal centre) derived subtypes of $d e$ novo DLBCL (Table 1). Paraffin-embedded DLBCL biopsy sections were available for subtyping six of the seven patients with de novo 
Table I Scoring system for subtyping de novo cases of DLBCL

\begin{tabular}{lcccc}
\hline CDI0 & + & - & - & - \\
BCL-6 & & - & + & + \\
MUMI & GC & non-GC & GC & non-GC \\
Subtype & GC
\end{tabular}

Cases were scored as positive when more than $30 \%$ of the tumour cells were positive. $\mathrm{GC}=$ germinal centre and non-GC = non-germinal centre. Empty boxes reflect that the presence or absence of this marker does not influence the scoring outcome.

DLBCL. The tumour from the patient whose serum was used for library screening was negative for CD10 and BCL-6 and positive for MUM1, suggesting that the patient had a poor prognosis nongerminal centre-derived subtype of DLBCL; this is consistent with the short survival time. Of the remaining five de novo DLBCL patients, four appeared to be non-germinal centre-derived, while the other was germinal centre-derived. Thus, the two de novo patients that showed serum reactivity with PASD1 were of a nongerminal centre-derived subtype of DLBCL. No biopsy material was available for the fourth patient mounting a humoral immune response to the PASD1 protein.

\section{DISCUSSION}

Using SEREX, we previously identified a novel antigen, OX-TES-1, that is recognised by circulating antibodies present in the serum of multiple patients with DLBCL. A full-length cDNA clone encoding OX-TES-1 had been cloned and this novel gene was named PAS domain containing 1 (PASD1). An alternatively-spliced form encoding a longer polypeptide has been named PAS domain containing 1 transcript variant 2 (PASD1_v2), with our sequence being transcript variant 1 (PASD1_v1).

Data in the UniGene folder Hs.160594 suggest that the PASD1 gene maps to chromosome band Xq28. A number of immunogenic tumour antigens with the characteristic CTA expression pattern have been mapped to this region, including MAGE-A, NY-ESO-1, LAGE-1, TRAG-3, CSAGE and SAGE (Scanlan et al, 2002). In addition, $\mathrm{Xq} 28$ has been identified as a genetic region that is altered in lymphomas and may contain lymphoma-associated oncogenes (Goyns et al, 1993; Vineis et al, 1999), one example being the high level amplification of Xq28 identified in some blastic mantle cell lymphomas (Bea et al, 1999).

Analyses of the gene structure indicated that the longer $P A S D 1 \_v 1$ cDNA appeared to have retained the sequence from intron 14, whereas this is removed in PASD1_v2. This alternative splicing results in the immediate introduction of a translational stop codon that truncates the PASD1_v1 protein. Many cancerassociated genes are alternatively-spliced, and it has been suggested that these may be extremely useful as cancer markers since there may be striking differences in the usage of alternatively-spliced variants between normal and tumour tissue (Caballero et al, 2001). There are also numerous publications reporting mRNAs containing retained intronic sequences, including the retention of CD44 introns in bladder cancer (Cooper, 1995), and the recently-described upregulation of the novel proapoptotic $\mathrm{BH} 3$-only splice variant of $B I M$ in prostate cancer cells (Liu et al, 2002). It should be noted that both PASD1 transcripts have been identified in testis, indicating that both forms are expressed in this normal tissue.

Both the PASD1 polypeptides share the same N-terminal 638-aa sequence, and analysis of the shared $\mathrm{N}$-terminal protein sequence indicated that PASD1_v1 and PASD1_v2 are novel PAS domain proteins. They are most closely related to the PAS family members CLOCK and NPAS2 that play an important role in regulating eukaryotic circadian rhythms (Dunlap et al, 1999; Dioum et al, 2002). Overlapping the PAS domains was a partial aryl-hydro- carbon receptor nuclear translocator domain (ARNT), aa 3-187. ARNT is the central heterodimerization partner of several transcription factors, including those containing the aryl-hydrocarbon (dioxin) receptor (AhR) and the hypoxia-inducible factor 1alpha (HIF-1alpha). A report that the AhR/ARNT heterodimer directly associates with oestrogen receptor- $\alpha$ and $-\beta$ is interesting in light of our identification of an LXXLL motif or nuclear receptor box in the N-terminus of the PASD1 protein that might mediate similar interactions (McInerney et al, 1998). While no studies have directly implicated AhR/ARNT in lymphomagenesis, it has been linked to leukaemogenesis (Salomon-Nguyen et al, 2000; Hayashibara et al, 2003). Recently, the AhR pathway has also been proposed as a novel drug target to control cell proliferation (Elferink, 2003).

Additional domains detected in the PASD1 protein suggest that this protein may be a nuclear PAS domain transcription factor. The predicted leucine zipper motif provides a potential nucleic acid-binding domain and there is a predicted nuclear localisation signal. Furthermore, proline- and glutamine-rich regions are commonly found in transcriptional activation domains, while activation domains rich in basic amino acids have also been described (Triezenberg, 1995).

Our studies of the combined expression of PASD1_v1 and PASD1_v2 mRNAs point towards PASD1 being a novel CTA, showing somatic tissue expression restricted to normal testis while also showing widespread expression in cancer patients. However, the PASD1 expression levels seen in the histologicallynormal tissues from patients with uterus, lung and small intestine cancer may indicate that PASD1 expression is an early event in carcinogenesis occurring before histological changes are apparent. Indeed, the expressions of many CTAs, including those that map to Xq28, have been linked to the DNA hypomethylation that occurs early during tumorigenesis. An association between p53 hypomethylation in peripheral blood lymphocytes and the development of lung cancer among male smokers has been reported (Woodson et al, 2001). This raises the possibility that changes in the hypomethylation of other genes might also be detectable in non-malignant tissues. We are, however, currently unable to explain why, for example, the uterine tissue from cancer patients should show PASD1 expression, while the tumour tissue does not, although one difference could be the cellular composition of normal and malignant tissue. Further studies will concentrate on characterising the expression of the PASD1 protein as this will have more significance as to the clinical utility of this molecule; monoclonal antibodies are currently being raised to both the short and long forms of the protein.

The PASD1 cDNA was cloned from a testis cDNA library, therefore it was necessary to confirm that the serum reactivity of DLBCL patients resulted from the expression of this gene. RT PCR studies confirmed the expression of PASD1_v1 in all DLBCLderived cell lines tested, while PASD1_v2 appeared to be expressed only in the cell lines derived from a poor prognosis non-germinal centre subtype of DLBCL. Expression of the longer PASD1_v2 protein may be a useful subtyping marker for the identification of high-risk DLBCL patients. Interestingly, Scanlan et al (2002) reported that the frequency of mRNA expression of CTAs such as NY-ESO-1, MAGE-A1, MAGE-A3 and SSX-2 was higher than the humoral response observed against the protein. This is consistent with our RT-PCR data, showing expression of PASD1_v1 in all seven DLBCL cell lines, although serum reactivity was only detected in $40 \%$ of patients. Of the four patients mounting a humoral immune response to PASD1, three (no biopsy material was available for subtyping the fourth patient) were associated with high-risk groups of DLBCL.

Until very recently, the SEREX technique had not been employed to identify B-cell lymphoma antigens. However, a study using serum from lymphoma patients, including those with 
DLBCL, to screen a testis library has recently been published (Huang et al, 2002). This study identified two known CTAs, HOMTES-14/SCP-1 and NY-ESO-1, and two novel antigens with a restricted normal expression pattern (HOM-NHL-21 and HOMNHL-23) that were not widely expressed in lymphomas or in solid tumours (Huang et al, 2002). The authors suggested that any new CTAs are likely to be expressed only infrequently in malignant tumours. This group also investigated the mRNA expression of 10 known CTAs in a range of non-Hodgkin's lymphomas and found that, while their expression in T-cell lymphomas was frequent, their expression in B-cell non-Hodgkin's lymphoma patients was comparatively rare (Xie et al, 2003). Such studies emphasise the importance of the identification of a novel CTA, particularly one that shows a relatively high frequency antibody response in B-cell lymphoma patients.

\section{REFERENCES}

Alizadeh AA, Eisen MB, Davis RE, Ma C, Lossos IS, Rosenwald A, Boldrick JC, Sabet H, Tran T, Yu X, Powell JI, Yang L, Marti GE, Moore T, Hudson Jr J, Lu L, Lewis DB, Tibshirani R, Sherlock G, Chan WC, Greiner TC, Weisenburger DD, Armitage JO, Warnke R, Levy R, Wilson W, Grever MR, Byrd JC, Botstein D, Brown PO, Staudt LM (2000) Distinct types of diffuse large B-cell lymphoma identified by gene expression profiling. Nature 403: $503-511$

Bea S, Ribas M, Hernandez JM, Bosch F, Pinyol M, Hernandez L, Garcia JL, Flores T, Gonzalez M, Lopez-Guillermo A, Piris MA, Cardesa A, Montserrat E, Miro R, Campo E (1999) Increased number of chromosomal imbalances and high-level DNA amplifications in mantle cell lymphoma are associated with blastoid variants. Blood 93: 43654374

Bernhard H, Salazar L, Schiffman K, Smorlesi A, Schmidt B, Knutson KL, Disis ML (2002) Vaccination against the HER-2/neu oncogenic protein Endocr Relat Cancer 9: 33-44

Brichard V, Van Pel A, Wölfel T, Wölfel C, De Plaen E, Lethé B, Coulie P, Boon T (1993) The tyrosinase gene codes for an antigen recognized by autologous cytolytic T lymphocytes on HLA-A2 melanomas. J Exp Med 178: $489-495$

Caballero OL, de Souza SJ, Brentani RR, Simpson AJ (2001) Alternative spliced transcripts as cancer markers. Dis Markers 17: 67-75

Cooper DL (1995) Retention of CD44 introns in bladder cancer: understanding the alternative splicing of pre-mRNA opens new insights into the pathogenesis of human cancers. J Pathol 177: 1-3

Coulie PG, Karanikas V, Colau D, Lurquin C, Landry C, Marchand M, Dorval T, Brichard V, Boon T (2001) A monoclonal cytolytic Tlymphocyte response observed in a melanoma patient vaccinated with a tumor-specific antigenic peptide encoded by gene MAGE-3. Proc Natl Acad Sci USA 98: 10290-10295

Dioum EM, Rutter J, Tuckerman JR, Gonzalez G, Gilles-Gonzalez M-A, McKnight SL (2002) NPAS2: A gas-responsive transcription factor. Science 298: 2385-2387

Dunlap JC, Loros JJ, Liu Y, Crosthwaite SK (1999) Eukaryotic circadian systems: cycles in common. Genes Cells 4: 1-10

Elferink CJ (2003) Aryl hydrocarbon receptor-mediated cell cycle control. Prog Cell Cycle Res 5: 261-267

Goyns MH, Hammond DW, Harrison CJ, Menasce LP, Ross FM, Hancock BW (1993) Structural abnormalities of the X-chromosome in nonHodgkin's-lymphoma. Leukemia 7: 848-852

Hans CP, Weisenburger DD, Greiner TC, Gascoyne RD, Delabie J, Ott G, Müller-Hermelink HK, Campo E, Braziel RM, Jaffe ES, Pan Z, Farinha P, Smith LM, Falini B, Banham AH, Rosenwald A, Staudt LM, Connors JM, Armitage JO, Chan W (2004) Confirmation of the molecular classification of diffuse large B-cell lymphoma by immunohistochemistry using a tissue microarray. Blood 103: 275-282

Hayashibara T, Yamada Y, Mori N, Harasawa H, Sugahara K, Miyanishi T, Kamihira S, Tomonaga M (2003) Possible involvement of aryl hydrocarbon receptor (AhR) in adult T-cell leukemia (ATL) leukemogenesis: constitutive activation of AhR in ATL. Biochem Biophys Res Commun 300: $128-134$
In conclusion, we have identified a novel CTA, PASD1, that warrants further study since its expression in both haematopoietic and nonhaematopoietic malignancies raises the possibility that this antigen may have a diagnostic or therapeutic use in a variety of cancers.

\section{ACKNOWLEDGEMENTS}

We thank Dr Barbara Guinn for her help in establishing the SEREX technique and all the clinicians, particularly Dr Chris Hatton, from the John Radcliffe Hospital and members of the Oxford Lymphoma Group, who helped us to obtain serum samples. This research was supported by the Leukaemia Research Fund and the Association for International Cancer Research.

Huang S, Preuss K-D, Xie X, Regitz E, Pfreundschuh M (2002) Analysis of the antibody repertoire of lymphoma patients. Cancer Immunol Immunother 51: 655-662

Jaffe SE, Harris LN, Stein H, Wardiman WJ (2001) WHO Classification: Tumours of Haematopoietic and Lymphoid Tissues. Lyon: IARC Press

Jäger D, Jäger E, Knuth A (2001) Immune responses to tumour antigens: implications for antigen specific immunotherapy of cancer. J Clin Pathol 54: $669-674$

Kozak M (1987) At least six nucleotides preceding the AUG initiator codon enhance translation in mammalian cells. J Mol Biol 196: 947-950

Liggins AP, Guinn BA, Hatton CS, Pulford K, Banham AH (2004) Serologic detection of diffuse large B-cell lymphoma-associated antigens. Int $J$ Cancer 110: $563-569$

Liu JW, Chandra D, Tang SH, Chopra D, Tang DG (2002) Identification and characterization of Bimgamma, a novel proapoptotic BH3-only splice variant of Bim. Cancer Res 62: 2976-2981

McInerney EM, Rose DW, Flynn SE, Westin S, Mullen T-M, Krones A, Inostroza J, Torchia J, Nolte RT, Assa-Munt N, Milburn MV, Glass CK, Rosenfeld MG (1998) Determinants of coactivator LXXLL motif specificity in nuclear receptor transcriptional activation. Genes Dev 12: 3357-3368

Nishikawa H, Tanida K, Ikeda H, Sakakura M, Miyahara Y, Aota T, Mukai K, Watanabe M, Kuribayashi K, Old LJ, Shiku H (2001) Role of SEREXdefined immunogenic wild-type cellular molecules in the development of tumor-specific immunity. Proc Natl Acad Sci USA 98: 14571-14576

Preuss KD, Zwick C, Bormann C, Neumann F, Pfreundschuh M (2002) Analysis of the B-cell repertoire against antigens expressed by human neoplasms. Immunol Rev 188: $43-50$

Rosenwald A, Wright G, Chan WC, Connors JM, Campo E, Fisher RI, Gascoyne RD, Muller-Hermelink HK, Smeland EB, Staudt LM (2002) The use of molecular profiling to predict survival after chemotherapy for diffuse large-B-cell lymphoma. N Engl J Med 346: 1937-1947

Sahin U, Türeci Ö, Schmitt H, Cochlovius B, Johannes T, Schmits R, Stenner F, Luo G, Schobert I, Pfreundschuh M (1995) Human neoplasms elicit multiple specific immune responses in the autologous host. Proc Natl Acad Sci USA 92: 11810-11813

Salomon-Nguyen F, Della-Valle V, Mauchauffe M, Busson-Le Coniat M, Ghysdael J, Berger R, Bernard OA (2000) The t(q21;p13) translocation of human acute myeloblastic leukemia results in a TEL-ARNT fusion. Proc Natl Acad Sci USA 97: 6757-6762

Scanlan MJ, Gure AO, Jungbluth AA, Old LJ, Chen Y-T (2002) Cancer/testis antigens: an expanding family of targets for cancer immunotherapy. Immunol Rev 188: $22-32$

The Non-Hodgkin's Lymphoma Classification Project (1997) A clinical evaluation of the International Lymphoma Study Group classification of non-Hodgkin's lymphoma. Blood 89: 3909-3918

Triezenberg SJ (1995) Structure and function of transcriptional activation domains. Curr Opin Genet Dev 5: 190-196

Türeci Ö, Sahin U, Zwick C, Neumann F, Pfreundschuh M (1999) Exploitation of the antibody repertoire of cancer patients for the identification of human tumor antigens. Hybridoma 18: 23-28 
van der Bruggen $\mathrm{P}$, Traversari C, Chomez P, Lurquin C, De Plaen E, Van den Eynde B, Knuth A, Boon T (1991) A gene encoding an antigen recognized by cytolytic $\mathrm{T}$ lymphocytes on a human melanoma. Science 254: $1643-1647$

Vineis P, Masala G, Costantini AS (1999) Does a gene in the Xq28 region increase the risk of non-Hodgkin's lymphomas? Working group for the Epidemiology of Hematolymphopoietic Malignancies in Italy. Ann Oncol 10: $471-473$
Woodson K, Mason J, Choi S-W, Hartman T, Tangrea J, Virtamo J, Taylor PR, Albanes D (2001) Hypomethylation of p53 in peripheral blood DNA is associated with the development of lung cancer. Cancer Epidemiol Biomarkers Prev 10: 69-74

Xie X, Wacker HH, Huang S, Regitz E, Preuss KD, Romeike B, Parwaresch R, Tiemann M, Pfreundschuh M (2003) Differential expression of cancer testis genes in histological subtypes of non-Hodgkin's lymphomas. Clin Cancer Res 9: $167-173$ 